\title{
Analyzing the Relationship between Organizational Culture and Silence with Organizational Health among Employers of Fars Maskan Bank
}

\author{
Asiyeh Foshat ${ }^{1} \&$ Reza Zarei $^{1}$ \\ ${ }^{1}$ Department of Educational Management, Marvdasht Branch, Islamic Azad University, Marvdasht, Iran \\ Correspondence: Reza Zarei, Department of Educational Management, Marvdasht Branch, Islamic Azad \\ University, Marvdasht, Iran. Tel: 98-917-712-7958. E-mail: Zareireza955@gmail.com
}

Received: October 19, 2016

Accepted: October 28, $2016 \quad$ Online Published: February 16, 2017

doi:10.5539/res.v9n1p234

URL: http://doi.org/10.5539/res.v9n1p234

\begin{abstract}
This study aims to analyze the relationship between organizational culture and silence with organizational health. The methodology of the study is correlation, and its statistical population is 642 that are all employers in Maskan Bank in Fars province. Sampling was executed through one-phase clustering sampling in which 130 persons were selected as statistical sample. Three questionnaires of organizational health (Hawaii et al., 1987), organizational culture (Hofstede, 1980), and organizational silence (Vacola \& Bouradas, 2005) were used for collecting data. Data was analyzed step to step using Pearson correlation coefficient and multiple regression tests. Results indicated that there is a significant inverse relationship between organizational culture and silence with organizational health (less than 0.01). Higher level managers' view of silence (among elements of organizational silence) and patriarchy (among elements of organizational culture) are capable of predicting organizational health in inverse. Other elements are not significantly capable in predicting organizational health.
\end{abstract}

Keywords: organizational health, organizational culture, organizational silence

\section{Introduction}

Organizational health is a new term that considers ability of an organization in effective duty performance, organizational growth and enhancement, and compatibility and developments for achieving progress and survival (Robert Miles, 1996). Other elements for organizational health are institutional unity, authority of manager, considerations, structuring, resource supplement, state of mind, and scientific deliberation (Alaqeband, 2009). Lack of attention toward organizational health and inadequate exploitation of workforce working in bank cause limitations in quality of services to customers, that consequently affects success and goal accomplishments in bank and then society. There is happiness and well-entrepreneurship in a bank or any servicing organization with a clear system of personnel and healthy support, that results in welfare, physical and mental health, consent, positive motivation, and quality of services. One of the variables influential on organizational health is organizational culture which is the character and personality of an organization. The condition of activities performed by individuals, the ways of their performance, their viewpoint to their job, interconnection with co-workers in organization all are effective. Future prospects are determined substantially by means of cultural values, beliefs, and norms (Toosi, 2007). Organizational culture development is one of the challenges of contemporary management in which organizational health is valuable. Organizations and mangers attempt to found and systemize a framework in which technological or other changes are accepted as basic cultural values. It seems organizational culture is effective on organizational health and personal expression (Aldeft, 2001).

A recently developed variable in organizations is organizational silence. It is a powerful force in organizations, yet it has not been studied or researched seriously. Morrison and Milliken introduced this term, and they represented that organizational silence is a social phenomenon created in and influenced by organization and its characteristic that include decision-making procedures, management, and employers' culture and understanding. Knowledge workers' silence is also significant issue in this regard. If the workers are silenced in an organization, their minds will be fossilized. When the knowledge workers, as the strategic capital of an organization, become silent, management should consider then the danger and its risks to organization (Danaifard, 2010). This behavioral phenomenon is also effective on effective organizational changes and development through 
preventing negative feedback. So, organization loses the ability of errors consideration and modification. Therefore, attention to this widespread problem in organizations is significant (Vacola, 2007).

Organizational silence is defined in three categories of submissive silence, defensive silence, and altruistic silence (Pinder \& Harlos, 2001; Avery \& Quinones, 2002; Korsgard, 1997). So due to emphasis on efficient and effective workforce in economics, the role of employers in bank servicing, and achieving organizational health with potent culture and away from silence, the researcher attempts to answer to the question: is there significant relationship between organizational culture and silence with organizational health among employers in Maskan Bank in Fars province?

\subsection{The Hypotheses of the Study}

The Primary Hypothesis:

There is a significant relationship between organizational culture and silence with organizational health.

The Secondary Hypothesis:

1) There is a significant relationship between elements of organizational culture and organizational health.

2) There is a significant relationship between elements of organizational silence and organizational health.

3) The elements of organizational culture are significantly capable in predicting organizational health.

4) The elements of organizational silence are significantly capable in predicting organizational health.

5) Organizational culture and silence are capable in predicting organizational health.

\section{Method}

The present study is applicable in its goal, and correlation in its method in collecting data. Statistical population in this study is 642 that are all formal and contract employers in Maskan Bank in Fars province during 2015. Sampling was one-phase random clustering in a way 10 cities were selected in Fars province in random, and the questionnaires were distributed among all employers in those branches. Three questionnaires of organizational health (Hawaii et al., 1987), organizational culture (Hofstede, 1980), and organizational silence (Vacola \& Bouradas, 2005) were used for collecting data. Data was analyzed step to step using Pearson correlation coefficient and multiple regression test.

\section{Results}

The Primary Hypothesis: There is a significant relationship between organizational culture and silence with organizational health.

Table 1. The matrix of organizational culture and silence with organizational health

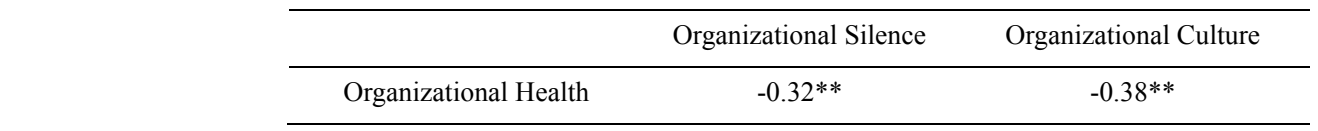

Significance level in $0.01 * *$ Significance level in $0.05^{*}$.

It is concluded from the output of Table 1 that there is a significant inverse relationship between organizational culture $(\mathrm{r}=0.38, \mathrm{p}<0.01)$ and organizational silence $(\mathrm{r}=0.32, \mathrm{p}<0.01)$ with organizational silence in level less than 0.01 .

The First Secondary Hypothesis: There is a significant relationship between elements of organizational culture and organizational health.

Table 2. The correlation matrix of organizational culture with organizational health

\begin{tabular}{ccccc}
\hline & Power Distance & Avoiding Risk & Individualist & Patriarchal \\
\cline { 2 - 5 } Significance level in $0.01^{* *}$ Significance level in $0.05^{*}$. & $-0.27^{* *}$ & $-0.33^{* *}$ & $-0.37^{* *}$ & $-0.37^{* *}$ \\
\cline { 2 - 5 }
\end{tabular}

Significance level in $0.01^{* *}$ Significance level in $0.05^{*}$. 
It is concluded from the output of Table 2 that all elements of organizational culture have a significant inverse relationship with organizational health in less than 0.01 .

The Second Secondary Hypothesis: There is a significant relationship between elements of organizational silence and organizational health.

Table 3. The correlation matrix of organizational silence with organizational health

\begin{tabular}{cccc}
\hline & Higher level Manager's View of Silence & Supervisor's View of Silence & Communicative Opportunities \\
\hline Organizational Health & $-0.71^{* *}$ & $-0.29^{* *}$ & 0.05 \\
\hline
\end{tabular}

Significance level in $0.01 * *$ Significance level in $0.05^{*}$.

It is concluded from the output of the Table 3 that manager's and supervisor's view of silence (an element in organizational silence) has a significant inverse relationship with organizational health in less than 0.01 .

The Third Secondary Hypothesis: The elements of organizational culture are significantly capable in predicting organizational health.

Table 4. The results of regression analysis for organizational health according to organizational culture in step to step method

\begin{tabular}{|c|c|c|c|c|c|c|c|c|c|c|}
\hline Step & Basic Variable & $\begin{array}{l}\text { Predicting } \\
\text { Variables }\end{array}$ & $\beta$ & $\mathrm{t}$ & $\mathrm{p}$ & $\mathrm{R}$ & $\mathrm{R}^{2}$ & $\mathrm{~F}$ & $\mathrm{df}$ & $\mathrm{p}$ \\
\hline First & $\begin{array}{c}\text { Organizational } \\
\text { Health }\end{array}$ & Patriarchy & -0.37 & -0.61 & 0.001 & 0.37 & 0.14 & 21.30 & 1,128 & 0.001 \\
\hline Second & Organizational Silence & $\begin{array}{c}\text { Patriarchy } \\
\text { Avoiding Risk }\end{array}$ & $\begin{array}{l}-0.28 \\
-0.21\end{array}$ & $\begin{array}{l}-3.16 \\
-2.35\end{array}$ & $\begin{array}{c}0.002 \\
0.02\end{array}$ & 0.42 & 0.17 & 13.80 & 127,2 & 0.001 \\
\hline
\end{tabular}

It is inferred from variance analysis test of the second step in Table 4 [ $F(2.127)=, 13.80, p<0.01]$ that there is a significant linear relationship between predicting variables (patriarchy and avoiding risk) and basic variables (organizational health, and patriarchy and avoiding risk), that they are significantly capable in predicting negative organizational health.

The Fourth Secondary Hypothesis: The elements of organizational silence are significantly capable in predicting organizational health.

Table 5. The results of regression analysis in organizational health

\begin{tabular}{ccccccccccc}
\hline Step & $\begin{array}{c}\text { Basic } \\
\text { Variable }\end{array}$ & $\begin{array}{c}\text { Predicting } \\
\text { Variables }\end{array}$ & $\boldsymbol{\beta}$ & $\mathbf{t}$ & $\mathbf{p}$ & $\mathbf{R}$ & $\mathbf{R}^{2}$ & $\mathbf{F}$ & $\mathbf{d f}$ & $\mathbf{p}$ \\
\hline Second & $\begin{array}{c}\text { Organizationa } \\
\text { 1 Health }\end{array}$ & $\begin{array}{c}\text { Manager's view } \\
\text { of silence }\end{array}$ & -0.71 & -11.58 & 0.001 & 0.71 & 0.51 & 134.09 & 1,128 & $\mathbf{0 . 0 0 1}$ \\
\hline
\end{tabular}

It is inferred from variance analysis test in Table $5[\mathrm{~F}(1.128)=134.09, \mathrm{p}<0.01]$ that there is a significant linear relationship between predicting variables (manager's view of silence) and basic variable (organizational health), and manager's view of silence is significantly capable in predicting negative organizational health.

The Fifth Secondary Hypothesis: Organizational culture and silence are capable in predicting organizational health. 
Table 6. The results of regression analysis for organizational health

\begin{tabular}{ccccccccccc}
\hline Step & Basic Variable & $\begin{array}{c}\text { Predicting } \\
\text { Variables }\end{array}$ & $\beta$ & $\mathrm{t}$ & $\mathrm{p}$ & $\mathrm{R}$ & $\mathrm{R} \mathrm{R}^{2}$ & $\mathrm{~F}$ & $\mathrm{df}$ & $\mathrm{p}$ \\
\hline First & $\begin{array}{c}\text { Organizational } \\
\text { Health }\end{array}$ & $\begin{array}{c}\text { Organizational } \\
\text { Culture }\end{array}$ & -0.38 & -4.72 & 0.001 & 0.38 & 0.14 & 22.29 & 1.128 & $\mathbf{0 . 0 0 1}$ \\
\hline
\end{tabular}

It is inferred from variance analysis test in Table $6[\mathrm{~F}(1.128)=22.29, \mathrm{p}<0.01]$ that there is a significant linear relationship between predicting variables (organizational culture) and basic variable (organizational health), and organizational culture is significantly capable in predicting negative organizational health.

\section{Discussion}

The Primary Hypothesis: The results of this hypothesis indicate that there is a significant inverse relationship between organizational culture and silence with organizational health. The results of this study are in line with results of studies by Lavenco (2003), Nasr Isfahani, Babapoor Dehkordi (2011), Taqvai and Inali (2015), and Muhammadzadeh (2015). But the results of this study are not in line with studies by Hawaii et al. (2007), Sohrabi Teymourloo et al. (2011), Abbaszadeh (2011), and Bahudini and Lesani (2015). It can be said in explaining this hypothesis that the management of an organization should know what measures, processes, and behaviors are required for increasing organizational health. It should be also informed about their needs, desires, and requests. Organizational culture needs to inspire values such as health in order to create a compatible culture according to organizational circumstances.

The First Secondary Hypothesis: The results of this study show that there is a significant inverse relationship among power distance, avoiding risk, patriarchy, and individualism. Findings in this section are not in line with findings by Hawaii et al. (2007), Seyyed Javadin (2009), and Sohrabi (2010). Risk-taking and power distance are decreased with less woman employer in organizations.

Banks are one of the main institutions in economic servicing that job satisfaction among its employers and their organizational culture and maturity are significant in their development. Thus, presenting efficient economic-financial services relies substantially on group works, leadership, and management.

The Second Secondary Hypothesis: The results of this study indicate that higher level managers' view of silence (one of the elements in organizational silence) is in significant inverse relationship with organizational health. The results in this regard are in line with Lavenco (2003), Nasr Isfahani and Babapoor Dehkordi (2010), Taqvai and Inali (2015), and Muhammadzadeh (2015).

It can be said in explaining this hypothesis that utilizing workforce appropriately is the main capital in every organization for desired developments and progresses, and an organization needs to listen employers' comments and ideas and participate them in decision-making and programming if it attempts to invigorate creativity and motivation among employers and also develop organizational health.

The Third Secondary Hypothesis: The results show that avoiding risk and patriarchy in organizational culture are capable in predicting negative organizational health. Findings of this study are not in line with findings by Hawaii et al. (2007), Sohrabi Teymourloo (2011), Abbaszadeh (2011), and Bahaudini and Lesani (2015).

Organizational culture is influential on maturity of organization. The more powerful and effective culture of an organization is, the more mature and efficient it is. Organizational culture is effective on goal-making, strategies, decision-making, participation, motivation, job satisfaction, creativity, commitment, discipline, hard-working, and stress. In fact if mangers desire to accomplish organizational health, they need to pay attention factors in organizational culture.

The Fourth Secondary Hypothesis: The results indicate that there is a significant linear relationship between predicting variables (higher level managers' view of silence) and basic variable (organizational health), and higher level managers' view of silence is significantly capable in predicting negative organizational health.

It can be said in explaining this hypothesis that higher level managers of an organization need to be more aware of the significance of management knowledge. They should consider social skills and effective communication in addition to developing their skills and knowledge in regard to their job. They should know that employers express themselves, suggest, criticize, and recommend instead of keeping silence when they are satisfied from their job and the condition of working milieu. 
The Fifth Secondary Hypothesis: The results indicate that there is a significant linear relationship between predicting variable (organizational culture) and basic variable (organizational health), and organizational culture is significantly capable of predicting negative organizational health. The results of this study in this regard are in line with results of studies by Lavenco (2003), Nasr Isfahani and Babapoor Dehkordi (2011), Taqvai and Inali (2015), and Muhammadzadeh (2015), but not in line with results of studies by Hawaii et al. (2007), Sohrabi Teymourloo et al. (2011), Abbaszadeh (2011), Bahaudini and Lessani (2015).

Evaluating and analyzing organizational health is a useful method in understanding about internal dynamism of an organization for developing its efficiency and competitiveness. So, bank managers need to focus on elements ignored beforehand. It is possible to increase organizational health by managers' reception of criticisms and comments by employers. It is noted that organizational health is a conceptual term determined based on employers views. Thus, it is possible to changes their negative views of organization through explanations and other kinds of information.

\section{References}

Alaqeband, A. (1999). School Organizational Health. Management in Education System Quarterly, Sixth course, 21, 14-33.

Aldeft, R. (2001). Organization Theory and Design (3rd ed., A. Parsaian, \& M. Arabi Trans.) Tehran: Cultural Research Center.

Avery, D. R., \& Quinones, M. A. (2002). Disentangling the effects of voice' the incremental roles of opportunity, behavior, and instrumentality in predicting procedural fairness. Journal of Applied Psychology, 87(9), 60-81. https://doi.org/10.1037/0021-9010.87.1.81

Crant, J. M. (2000). Proactive behavior in organizations. Journal of Management, 26, 435-462. https://doi.org/10.1177/014920630002600304

Danaifard, H., \& Panahi, B. (2010). Analyzing Views of Jobs among Employers of State Organizations (defining organizational silence and organizational silence behaviors). Change Management Quarterly, 3, 19.

Greenberg, J., \& Edwards, M. S. (2009). Voice and Silence in Organizations. Bingley, UK: Emerald Press.

Korsgaard, M. A., Meglino, B. M., \& Lester, S. W. (1997). Beyond helping: Do other-oriented values have broader implications in organizations? Journal of Applied Psychology, 82, 160-177. https://doi.org/10.1037/0021-9010.82.1.160

Miles, M. B. (1996). Planned change and organizational health. In Figure and ground. New York, Mc Grow Hill.

Pinder, C. C., \& Harlos, K. P. (2001). Employee silence: Quiescence and acquiescence as responses to perceived injustice. Research in personnel and Human Resources Management, 20(6), 331-369. https://doi.org/10.1016/s0742-7301(01)20007-3

Podsakoff, P. M., Mackenzie, S. B., Paine, J. B., \& Bachrach, D. G. (2000). Organizational citizenship behaviours: A critical review of the theoretical and empirical literature and suggestions for future research. Journal of Management, 26, 513-563. https://doi.org/10.1177/014920630002600307

Slade, M. R. (2008). The Adaptive Nature of Organizational Silence: A Cybernetic Exploration of the Hidden Factory. The faculty of the graduate school of education and human development of the George Washington University.

Toosi, M. (2007). Organizational Culture. Tehran: Publication of State Management Higher Education.

Vakola, M., \& Bouradas, D. (2005). Antecedents and consequences of organizational silence: An empirical investigation. Employee Relations, 27(5), 441-458. https://doi.org/10.1108/01425450510611997

\section{Copyrights}

Copyright for this article is retained by the author(s), with first publication rights granted to the journal.

This is an open-access article distributed under the terms and conditions of the Creative Commons Attribution license (http://creativecommons.org/licenses/by/4.0/). 